\title{
Assessment of Recreational Facilities in Federal Capital City, Abuja, Nigeria
}

\author{
Cyril Kanayo Ezeamaka and Olumide Akinwumi Oluwole
}

Received: 29102014 / Accepted: 1003 2015 / Published online: 30062016

(C) 2016 Faculty of Geography UGM and The Indonesian Geographers Association

\begin{abstract}
Abuja Master Plan provided development of adequate Green Areas and other Recreational Facilities within the Federal Capital City (FCC), as part of its sustainability principles and provided for these recreational facilities within each neighborhood (FCDA, 1979). However, there have been several recent foul cries about the negative development of recreational facilities and the abuse of the Master Plan in the FCC. The motivation for carrying out this study arose from the observation that recreational facilities in Phase 1 of the Federal Capital City Abuja are not clearly developed as intended by the policy makers and thus, the need to identify the recreational facilities in the Phase 1 of FCC and observe their level of development as well as usage. The field survey revealed that the Central Business District and Gazupe have higher numbers of recreational facilities with 45 and 56. While Wuse II (A08) and Wuse II (A07) Districts have lesser recreational facilities with 10 and 17 . The field survey further revealed that all the districts in Phase 1 have over $35 \%$ cases of land use changes from recreational facilities to other use. The survey shows that over $65 \%$ of these recreational facilities are fully developed. The study also shows that just about $11 \%$ of the recreational sporting facilities were developed in line with the Abuja Master Plan in Phase 1. The study revealed that recreational facilities in Phase 1 of the FCC, Abuja has not being developed in compliance with the Abuja Master Plan.
\end{abstract}

Keywords: Recreational facilities, park, open space, green area, master plan, compliance

Abstrak Master Plan Abuja menyediakan pengembangan Area Hijau yang memadai dan Fasilitas rekreasi lainnya dalam Federal Capital City (FCC) - Ibu Kota Federal -, sebagai bagian dari prinsip-prinsip keberlanjutan dan menyediakan fasilitas-fasilitas rekreasi dalam setiap lingkungan (FCDA, 1979). Namun, ada beberapa kecaman tentang pembangunan negatif fasilitas rekreasi dan penyalahgunaan Master Plan di FCC. Motivasi untuk melaksanakan penelitian ini muncul dari hasil pengamatan bahwa pembangunan fasilitas rekreasi di Tahap 1 dari Federal Ibu Kota Abuja tidak jelas sebagaimana yang dimaksud oleh pembuat kebijakan; dengan demikian dibutuhkan upaya identifikasi fasilitas rekreasi di Tahap 1 dari FCC dan kemudian dimati tingkat perkembangan serta penggunaan. Survei lapangan mengungkapkan bahwa Central Business District dan Gazupe memiliki jumlah dari fasilitas rekreasi yang lebih tinggi yaitu 45 dan 56. Sementara Kabupaten Wuse II (A08) dan Wuse II (A07) memiliki fasilitas rekreasi yang lebih rendah yaitu 10 dan 17. Survei lapangan lebih lanjut mengungkapkan bahwa semua kabupaten di Tahap 1 memiliki lebih dari $35 \%$ kasus perubahan penggunaan lahan dari fasilitas rekreasi untuk penggunaan lainnya. Survei menunjukkan bahwa lebih dari $65 \%$ dari fasilitas rekreasi telah dibangun sepenuhnya. Penelitian ini juga menunjukkan bahwa hampir 11\% dari fasilitas rekreasi olahraga dikembangkan sejalan dengan Rencana Induk Abuja pada Tahap 1. Hasil penelitian menunjukkan bahwa fasilitas rekreasi di Tahap 1 dari FCC Abuja belum dikembangkan sesuai dengan Master Plan Abuja.

Kata kunci: fasilitas rekreasi, taman, ruang terbuka, area hijau, rencana induk, kepatuhan

\section{Introduction}

Recreation is an essential part of human life and exists in many different forms, which are shaped naturally by individual interests but also by the surrounding social construction. Recreational activities can be communal or solitary, active or passive, outdoors or indoors, healthy or harmful, and useful for society. The Abuja Master Plan was prepared in 1979 by the International Planning Associates (IPA) for the development of a new capital for Nigeria. Jibril [2010] observed that full implementation of the Plan commenced in the early 1980s. The Master Plan is the guiding principle for the orderly development of the City and it was meant to be a beautiful city that would

Cyril Kanayo Ezeamaka and Olumide Akinwumi Oluwole

Department of Geography, Nigerian Defence Academy

P.M.B. 2109, Kaduna, Nigeria

Email: cyrilezeamaka@gmail.com be sustainable. As part of its sustainability principles, the Abuja Master Plan provided development of adequate Green Areas and other Recreational Facilities within the Federal Capital City (FCC) of Abuja The Abuja Master Plan provides for these recreational facilities within each neighborhood [FCDA, 1979].

Green Areas are strictly reserved as recreational parks, professionally landscaped with grass and flora to retain their natural splendor and at the same time avoid disruption of the ecosystem. Numerous parks dot the entire face of the city. Private developers who are in the best position to guarantee a very high standard of maintenance manage the parks. The most prominent of the parks are the Millennium Park and Unity Fountain in Central Business District, Abuja Zoological Gardens in Garki District, Maitama Amusement Park and the IBB Golf Course in Maitama District, Wonder Land by City gate, among others. Abuja's parks are 
in most cases bordered by rivers or streams from which fountains are generated and through which its grasses, flora and trees are watered, preserving a cool and green atmosphere even in the city's hottest months (February and March). However, there have been several recent foul cries about the negative development of recreational facilities and the abuse of the master plan in the Federal Capital City (FCC).

For the purpose of this study, the recreational facilities includes green areas, open space, parks and gardens, sports facilities; divided into natural and manmade within the Federal Capital City, (FCC) Abuja. The natural landscape of the Federal Capital City is quite charming and distinctively of aesthetic appeal. The Phase 1 of the Federal Capital City, Abuja is an already fully built up land with all the necessary infrastructures put in place making it comparable to a modern city in the world [FEEDS, 2006]. However, previous studies have shown that the recreational facilities are not developed in line with the Master Plan or land use have been changed [Jibril, 2010; Falade, 1999] Basically, the motivation for carrying out this study arose from the observation that recreational facilities in Phase 1 of the Federal Capital City Abuja are not clearly developed as intended by the policy makers and thus, the need to identify these recreational facilities and their level of compliance. Also Jibril [2010] and Falade [1999] observed that the City grew in both development and population. The provisions of these 'Green Areas' became a subject of abuse and a lot of the areas were taken over by developers and converted to other land uses thereby leading to the abuse and distortion of the Abuja Master Plan. This paper attempts to identify the recreational facilities in the Phase 1 of FCC and observe their level of development as well as usage.
Aim: The aim of this paper is to identify and examine the compliance on the development of recreational facilities within Phase I of the FCC, Abuja.

Objectives: The objective of this paper is to collect information on the recreational facilities; open space, parks, green areas and gardens in Phase 1 of the FCC, and examine their conformity as well as their levels of development.

\section{The Methods}

The Federal Capital Territory (FCT), Abuja falls within latitude $70251 \mathrm{~N}$ and 90201 North of the Equator and longitude $60451 \mathrm{E}$ and 70391 East. It covers an area of about 8,000 square kilometers [FCDA, 1998]. The Federal Capital Territory was carved out of Niger State, Plateau State and Kwara State. Niger State contributed the largest proportion to the Federal Capital Territory, accounting for 6,738 square kilometers $(84.2 \%)$, while Plateau State contributed 903.8square kilometers, (11.3\%) and Kwara State gave $0.5 \%$ that is 358.2 square kilometers [Udeh, 2010]. By virtue of the central location of the FCT within the national context it is placed entirely in the Middle Belt region of Nigeria. Figure 1 shows the location of Abuja. It is bounded to the north by Kaduna State, and by Nassarawa State to the East and Southeast, to the Southwest by Kogi State and to the West by Niger State. Abuja is centrally located and is easily accessible from all parts of Nigeria as shown in Figure 1.

The Abuja Master Plan, the FCC was conceived to accommodate estimated population of 157,750 persons in residence on inauguration in 1986, then 485,660 persons in $1990,1,005,800$ persons in 1995 and $1,642,100$ persons in 2000 [FCDA, 1979]. It would then grow to a maximum population of approximately 3.1

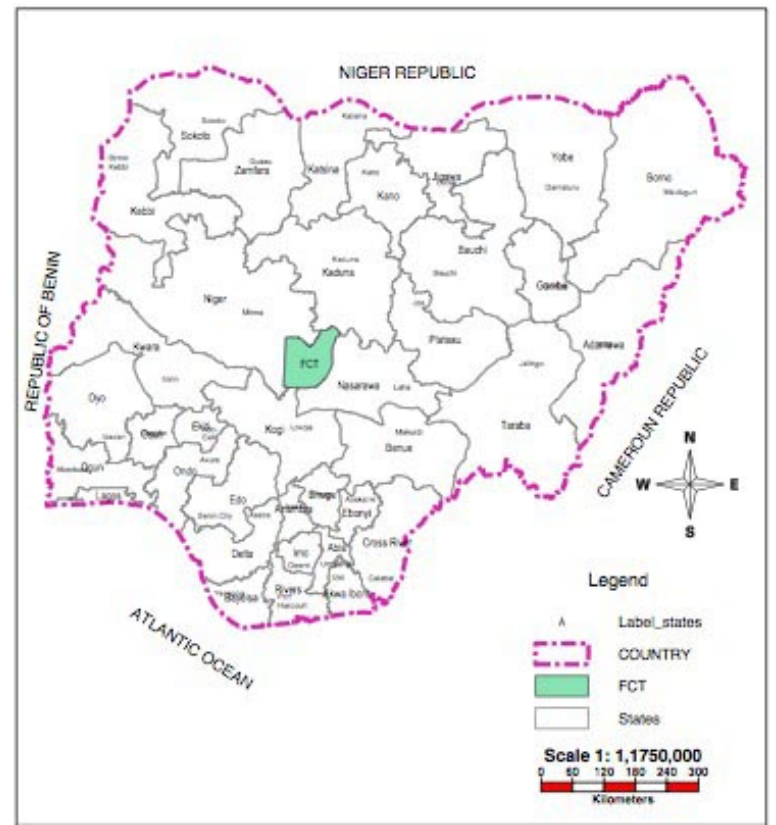

(Source: AGIS, 2014)

Figure 1. Nigeria Showing FCT. 


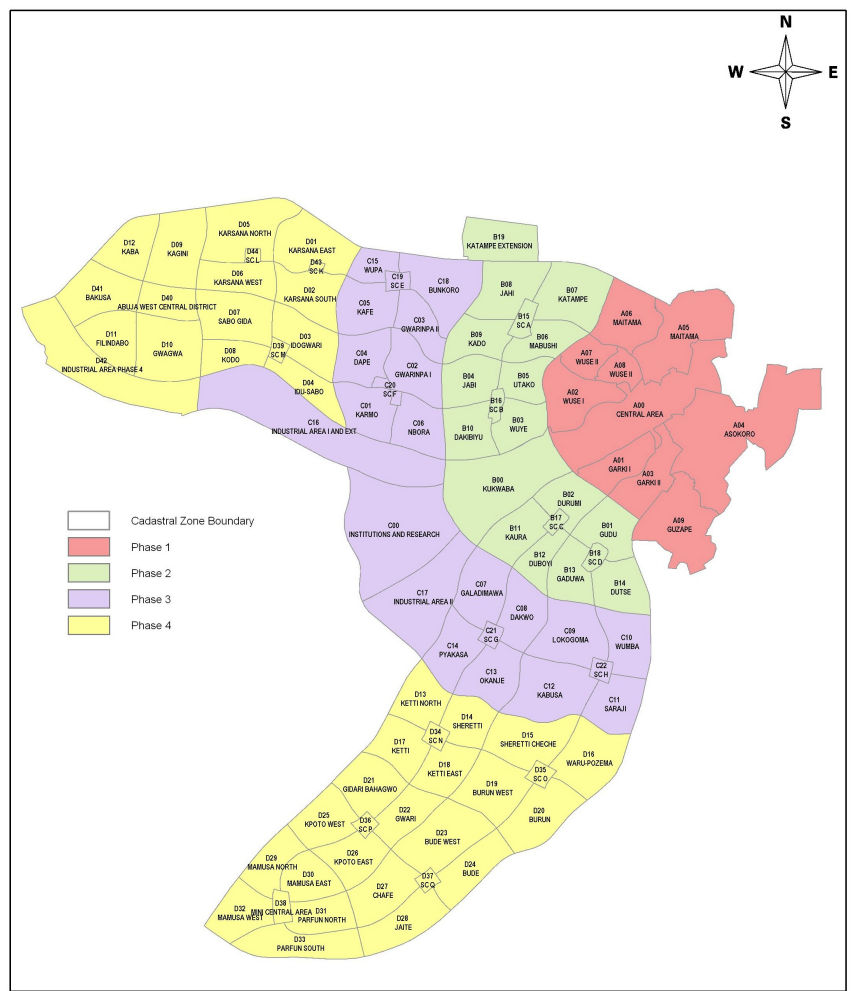

Figure 2. Federal Capital City Showing Four Phases of Development

million, after which the population growth would be accommodated outside the city in the Satellite towns [Udeh, 2010]. There are ten (10) districts in Phase I, namely: Central Business District, Garki, Wuse, Garki II, Asokoro, Maitama, Maitama II, Wuse II (A07), Wuse II (A8) and Guzape. Phase I is fully developed with exception of the Central Business District (CBD) and Guzape District as shown in Figure 2.

The Central Business District (CBD) is the hub of both the city and the nation, and the seat of government. The other districts are meant for residential development for both public and private developers.

\section{Review of Relevant Literatures}

Falade [1999] noted that the recreational facilities couldn't be mentioned without other related terms like urban open space, park and gardens, leisure and recreation resource management and open space. He further observed that there is a positive correlation between the provision of parks and gardens and outdoor leisure pursuits as provision will induce usage. There is clear need to provide a concise definition of these related terms.

Open Space: An open space is either "land not built upon, which may be either natural or man made, or land developed as garden and recreation grounds, or undeveloped land which has value for recreational purposes, amenity and conservation of land and other natural resources, historic or scenic landscapes, or area of outstanding natural beauty such as water areas, river valleys, hills, mountains, lakes, oceans and bays" [Falade, 1999].

Parks and Gardens: Park originally means a hunting ground attached to the house of a gentleman, like the Persian Gardens of the Aristocrats. With rapid growth and development in Europe in the 19th century, the meaning of the word park changed. Falade [1999] observes that park as any land laid out as space essential for public use. Thus for purpose of public use and public ownership and hence was qualified as public park. These two attributes do differentiate public parks from other types of gardens and open space.

Gardens: Garden has both ordinary and specialized meaning in landscape design. A garden is a piece of ground devoted too the cultivation of flowers, fruits and vegetables. However, for the professionals, a garden can give two separate pleasures; the pleasure of the growing plants with its individual beauty and the pleasure of the whole garden as a whole, as a world tolive in and to look at.

Recreation: Knudson [1980] defined recreation as an activity engaged in by the individuals after work, an activity that rejuvenates, recreates and builds the individual anew recreational sport is any sport or game where the participant plays for fun not for reward and aim to maintain or improve physical ability and skills. However, the understanding of leisure, Parker [1974] defined leisure in relation with time as the time an individual has, free from work or other daily chores, which may be utilized for recreation. Thus leisure connotes time uncommitted to the necessities of life.

Jibril [2010] opined that the basic concept of the Abuja Master Plan is the "Neighborhood Concept". The 
Plan provides for Residential enclave with a threshold population of 5000 people served with common facilities. This allows its inhabitants get the basic urban needs within the proximity of their varied homes. A group of neighborhoods however form a district and the districts in turn are served by district centers with several facilities such as schools, hospitals, fire stations, etc. Kenzo-Tange and Urtec [1981] described "Open Spaces, landscaping and vista planning as closely interrelated elements". Open spaces are therefore categorized in the "urban design" of Abuja as; Street Space, Three Arms Gardens, (the 'three arms' implies the Executive, Legislative and Judicial arms of the Federal Government of Nigeria and the locations of these buildings in the City of Abuja are known as the 'three arms zone'), Green Buffer Zone in the "Three Arms Zone”, Ministries' Gardens, National Mall, National square/City Squares, Green Areas in the Cultural Zone, Pedestrian Ways (including squares and porticos), Courtyards in Ministries' Zone and the Central Business District Zone and Green Zone along Expressways.

The Green Areas provided for in the Abuja Master Plan made provisions for both developable and un-developable green areas. The 'Developable Green Areas' includes the following; Open Spaces, Recreational Facilities, Parks and Gardens, Children Playgrounds, Out Door Games, Sport Centers, and National, District/Neighborhood Parks, While the 'Un-developable Green Areas' includes the following; Green stretches along valleys, Riverbeds, Hilly patches and some incidental open spaces. This concept of 'undevelopable green areas' does not in any way connote lack of technology or financial muscles by woulddevelopers to turn these areas round for some form of economic activities. It is rather aimed at preserving the environment and enhancing the beauty of the City of Abuja. In traditional Nigerian town planning, parks and gardens are in the private sector rather than the public sector. Thus, an affluent compound might have an inner courtyard with trees and birds and gardens. In the twentieth century the Nigerian town planning there is often 'space open' some of it reserved for future government use and are referred to as 'Land Bank' by the Master Plan. Only recently has there developed a notion of urban parks and public gardens; due, in part, to close proximity to rural open space and also to the utilitarian notion of land use. Within the FCC and FCT, provisions have been made for the development of a variety of parks and gardens [FCDA, 1979]. The Abuja Master Plan covers the following;

i. Central Parkway: the major open space unit for the FCC is the central linear parkway. This space is also designed to accommodate private vehicle movement in a park-like setting, the available land is more than adequate to accommodate other uses, which includes schools, burial purposes. However, the overall concept of open space' is primarily recreational and aesthetic effect.

ii. Central Park: located within the CBD and anticipated to accommodate polo field/ race track, a national festival ground and zoo. iii. Other Open Spaces and Parks: other open spaces and parks/gardens of large-scale nature should occur along the radial parkways of the city. At district level open spaces, parks and gardens should be provided in addition to the open space system provided by drainage course and many unbuildable areas. iv. National Arboretum: located between the National Assembly and Aso Hill and covering an area of 50 to 100 hectares. To be developed into National Arboretum and Botanical garden.

The Master Plan also provided for regional recreational facilities such as the National Park, National Game Park, National Monument/Wilderness, Holiday Village (Unity Village), National Museum, Cinemas and Theaters among others. The motives behind the provision of the Greens in the City Plan are for good habitation, beautification and conservation purposes. They were also created to protect hilltops, side hills and streams/rivers courses in their natural form.

\section{Data Collection and Analysis}

Data used for this study were collected from primary and secondary sources. Primary data collection involved field surveys, oral interviews and physical observations of recreational facilities in the study area. Secondary data were gathered from existing literature related to recreational facilities and the recreational facilities as provided in the Abuja Master Plan. The data collected were presented in tables describing the recreational facilities, type and level of compliance and development in Phase 1 of the FCC, Abuja.

\section{Results and Discussions}

The field survey revealed that the Central Business District and Gazupe have higher numbers of recreational facilities with 45 and 56. However, Wuse II (A08) and Wuse II (A07) District have the least recreational facilities with 10 and 17 as shown in Table 1.

This is as a result of conversion and land use violation in a quest to keeping to the land needs of the residents. This is largely due to lack of adequate investment in infrastructure by FCTA thereby making the Phase 1 a hot spot. The consequences are land speculation, encroachment and several environmental problems such as creation of slums and squatter settlements, environmental deterioration, and an inefficient urban development pattern. The field survey further revealed that all the districts in Phase 1 have over $35 \%$ cases of land use changes from recreational facilities to other use. Maitama, Wuse, Asokoro, Wuse 11 and Maitama 11 have very high rate of illegal land use and land use violation as shown in figure 4. Further analysis shows that five Districts in Phase no longer have recreational sports facilities.

The level of development of recreational facilities in the city is very crucial to the success of the tourism 
Indonesian Journal of Geography, Vol. 48 No. 1, June $2016: 21$ - 27

Table 1. Distribution of Recreational Facilities in Phase 1 of FCC, Abuja

\begin{tabular}{llllll}
\hline District (Cad Zone) & Parks \& Gardens & Open Space & Green Area & Sports Facilities & Total \\
\hline Central Area (A00) & 5 & 20 & 19 & 1 & 45 \\
Garki I (A01) & 4 & 5 & 13 & 2 & 24 \\
Wuse (A02) & 2 & 9 & 15 & 2 & 28 \\
Garki II (A03) & 10 & 5 & 16 & 2 & 33 \\
Asokoro (A04) & 6 & 8 & 17 & 2 & 33 \\
Maitama (A05) & 1 & 7 & 12 & 2 & 22 \\
Maitama II (A06) & 15 & 1 & 8 & 2 & 26 \\
Wuse II (A07) & 4 & 7 & 6 & 2 & 19 \\
Wuse II (A08) & 4 & 3 & 3 & 2 & 12 \\
Guzape (A09) & 9 & 21 & 23 & 3 & 56
\end{tabular}

Source: Author's Fieldwork (2014)

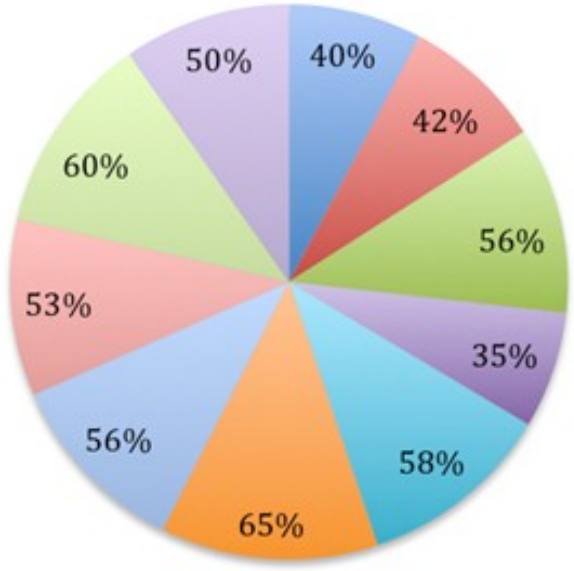

$$
\begin{aligned}
& =\text { Central Area } \\
& =\text { Garki I (A01) } \\
& =\text { Wuse (A02) } \\
& =\text { Garki II (A03) } \\
& =\text { Asokoro } \\
& =\text { Maitama (A05) } \\
& =\text { Maitama II (A06) } \\
& =\text { Wuse II (A07) } \\
& =\text { Wuse II (A08) } \\
& =\text { Guzape }
\end{aligned}
$$

Table 2. Development Status of Recreational Facilities in Phase 1 of Federal Capital City

\begin{tabular}{lllllllll}
\hline & \multicolumn{2}{l}{ Parks \& Gardens } & Open Space & Green Area & \multicolumn{2}{l}{ Sports Facilities } \\
\cline { 2 - 8 } & $\begin{array}{l}\text { No. De- } \\
\text { veloped }\end{array}$ & $\begin{array}{l}\text { No. Not } \\
\text { Developed }\end{array}$ & $\begin{array}{l}\text { No. Devel- } \\
\text { oped }\end{array}$ & $\begin{array}{l}\text { No. Not } \\
\text { Developed }\end{array}$ & $\begin{array}{l}\text { No. Devel- } \\
\text { oped }\end{array}$ & $\begin{array}{l}\text { No. Not } \\
\text { Developed }\end{array}$ & $\begin{array}{l}\text { No. Devel- } \\
\text { oped }\end{array}$ & $\begin{array}{l}\text { No. Not } \\
\text { Devel- } \\
\text { oped }\end{array}$ \\
\hline $\begin{array}{l}\text { Central Area } \\
\text { (A00) }\end{array}$ & 2 & 3 & 0 & 20 & 4 & 36 & 0 & 1 \\
Garki I (A01) & 4 & 1 & 4 & 1 & 5 & 15 & 1 & 1 \\
Wuse (A02) & 2 & 0 & 3 & 6 & 9 & 6 & 0 & 0 \\
Garki II (A03) & 7 & 3 & 1 & 4 & 10 & 6 & 0 & 0 \\
Asokoro (A04) & 4 & 2 & 13 & 10 & 8 & 13 & 1 & 0 \\
Maitama (A05) & 1 & 0 & 5 & 2 & 11 & 6 & 1 & 1 \\
Maitama II & 11 & 4 & 1 & 1 & 3 & 5 & 0 & 0 \\
(A06) & & & & & & & & 0 \\
Wuse II (A07) & 4 & 0 & 5 & 2 & 6 & 0 & 0 & 0 \\
Wuse II (A08) & 4 & 0 & 3 & 0 & 3 & 0 & 0 & 0 \\
Guzape (A09) & 9 & 0 & 21 & 0 & 33 & 0 & 3 & 0 \\
Total & 48 & 13 & 56 & 46 & 92 & 87 & $6(25 \%)$ & $3(12.5 \%)$ \\
\hline
\end{tabular}

Source: Fieldwork [2014] 
Table 3. Compliance to Land Use of Recreational Facilities in Phase 1 of Federal Capital City

\begin{tabular}{|c|c|c|c|c|c|c|c|c|}
\hline & \multicolumn{2}{|c|}{ Parks \& Gardens } & \multicolumn{2}{|c|}{ Open Space } & \multicolumn{2}{|c|}{ Green Area } & \multicolumn{2}{|c|}{ Sports Facilities } \\
\hline & Total No & $\begin{array}{l}\text { Compliance } \\
\text { to Land Use }\end{array}$ & Total No & $\begin{array}{l}\text { Compli- } \\
\text { ance to } \\
\text { Land Use }\end{array}$ & Total No & $\begin{array}{l}\text { Compli- } \\
\text { ance to } \\
\text { Land Use }\end{array}$ & Total No & $\begin{array}{l}\text { Compliance } \\
\text { to Land Use }\end{array}$ \\
\hline $\mathrm{CBD}(\mathrm{A} 00)$ & 5 & 2 & 20 & 12 & 40 & 4 & 1 & 0 \\
\hline Garki I (A01) & 4 & 4 & 5 & 2 & 20 & 15 & 2 & 1 \\
\hline Wuse (A02) & 2 & 2 & 9 & 3 & 15 & 9 & 2 & 1 \\
\hline Garki II (A03) & 10 & 9 & 5 & 2 & 16 & 10 & 2 & 0 \\
\hline Asokoro (A04) & 6 & 8 & 23 & 10 & 21 & 6 & 2 & 0 \\
\hline $\begin{array}{l}\text { Maitama } \\
\text { (A05) }\end{array}$ & 1 & 4 & 7 & 2 & 17 & 4 & 2 & 0 \\
\hline $\begin{array}{l}\text { Maitama II } \\
\text { (A06) }\end{array}$ & 15 & 10 & 1 & 0 & 8 & 4 & 2 & 0 \\
\hline Wuse II (A07) & 4 & 8 & 7 & 0 & 6 & 2 & 2 & 0 \\
\hline Wuse II (A08) & 4 & 6 & 3 & 0 & 3 & 1 & 2 & 0 \\
\hline Guzape (A09) & 9 & 0 & 21 & 0 & 33 & 0 & 3 & 0 \\
\hline Total & 60 & $53(88.3 \%)$ & 101 & $31(30.7 \%)$ & 179 & $55(30.7 \%)$ & 18 & $2(11.1 \%)$ \\
\hline
\end{tabular}

Source: Fieldwork (2014)

industry and well being of the residents of the city. The Phase 1 of the FCC, Abuja has great potentials that could make her a viable recreational destination for many Nigerians. The survey on the developmental status shows that over $65 \%$ of these recreational facilities are fully developed expect for those in Central Business District and Gazupe District. This is due to the fact that both Districts are not fully developed. The survey revealed that there are 13 parks and gardens, 46 open spaces, 87 green areas and 3 sports facilities yet to be developed. It further shown that only $25 \%$ of the sports facilities is developed while $12.5 \%$ is yet to be developed and $62.5 \%$ have been conversed to other changes as shown in Table 2. The implications of these are that sporting facilities are lacking within Phase 1 and many residents have to travel to other places for this purpose.

The field survey on the compliance to land use of recreational facilities revealed that 53 parks and gardens were complaining out of the 66 , while only 2 of the 18 of sports facilities, and 86 out of the 280 green areas and open spaces were developed in compliance to the Master Plan as shown in Table 3. The result of shows clearly that there are many parks and gardens within Phase 1 of the FCC. The result further shows that abuse of power and office by land administrator in Abuja are major causes of these illegal conversions. The Abuja Master Plan is indeed a vital reference

\section{References}

Falade, B. (1999). Location of Recreational Facilities, Parks and Gardens Development in the Context of the Abuja Master Plan. In Kalgo, M. S. U. and Olatubosun, A (Eds), The Review of Abuja Master Plan. Fountain Publications, Ibadan, Nigeria. Federal Capital Development Authority (FCDA). point for land administration and management in Abuja [Mabogunje, 1999] but has been highly abused

\section{Discussion of Findings and Implications}

The findings of this study shows that there are illegal land use changes, violation of land use, illegal development and encroachment This study has observed that recreational facilities are commonly used by squatters within the city. The study also shows that just about $11 \%$ of the recreational sporting facilities were developed in line with the Abuja Master Plan in Phase 1 as seen in Table 3. The implications of these are lack of adequate recreational facilities, residential and commercial development on recreational facilities, environmental deterioration, blockage of sewage lines and drainage lines within the city.

\section{Conclusion}

The study revealed that recreational facilities in Phase 1 of the FCC, Abuja has not being developed in compliance with the Abuja Master Plan. It also revealed that there are few sporting recreational facilities in the area. Recreational facilities are vital to the well being of man, hence, future developments of recreational facilities in FCC should ensure to be in line with the Abuja Master Plan.

(1979). The Master Plan For Abuja The New Federal Capital of Nigeria. FCDA, Abuja. Federal Capital Economic and Development Strategy (FEEDS). (2006). Our Vision of Abuja, MFCT. Abuja, Nigera. Jibril, I. U. (2010). The Return of the Greens in Abuja, Nigeria's new Capital City. FIG Congress 2010. Facing the Challenges - Building 
the Capacity, Sydney, Australia, 11-16 Parker, S. (1974). The sociology of Leisure. Kenzo- Tange and Urtec (1981). Central Intermediate Publication Service. New York. Area Urban Design, Federal Capital Udeh, A. U. (2010). Impact of Development of the Development Authority (FCDA). Tokyo. Federal Capital City, Abuja on Selected Settlements Knudson, D. M. (1980). Outdoor Recreation, in Karu Local Government Area, Nasarawa Macmillam Company. New York, USA. State, Nigeria. Unpublished M. Tech Thesis, Mabogunje, A. L. (1999). Abuja; The Promise, The Performance and the Prospects. In Kalgo, M. S. U. and Olatubosun, $A$ (Eds). The Review of Abuja Master Plan. Fountain Publications, Ibadan. Federal University of Technology, Minna. 